\title{
Impact of passive climate adaptation measures and building orientation on the energy demand of a detached lightweight semi-portable building
}

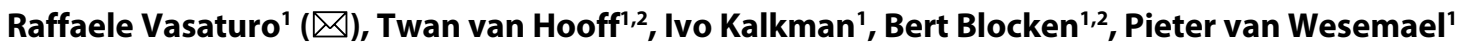 \\ 1. Department of the Built Environment, Eindhoven University of Technology, Eindhoven, the Netherlands \\ 2. Department of Civil Engineering, KU Leuven, Leuven, Belgium
}

\begin{abstract}
The building energy demand for heating and cooling is changing due to climate change. The adoption of climate change adaptation measures at the building scale aims at limiting heating and cooling demands. In previous studies on adaptation measures little attention has been paid to lightweight semi-portable buildings, which are increasingly used to temporarily house the growing number of small households (1-2 persons) in peripheral and derelict areas. In this paper the impact of passive climate adaptation measures and building orientation on heating and cooling demands is assessed for a detached, lightweight, semi-portable residential building by means of building energy simulations (BES), considering two climate scenarios for the Netherlands: current climate and a future climate (2050). The results show that the most efficient adaptation measure consists in a combination of exterior solar shading and an increase of thermal resistance of the building envelope, which reduces the annual heating and cooling demand - averaged over eight building orientations - by $11 \%$ for the current climate and $15 \%$ for the future climate. The impact of building orientation varies according to the climate scenario. Compared to the average over the eight orientations considered, the annual cooling demand for a single orientation varies between about $-31 \%$ and $+22 \%$ and between about $-24 \%$ and $+18 \%$ for the current and future climate, respectively. For the case without adaptation measures, optimizing the building orientation leads to annual total energy savings of about $4 \%$ for the current and $3 \%$ for the future climate.
\end{abstract}

\section{Keywords}

building energy simulation,

heating demand,

cooling demand

passive climate adaptation measures, building orientation,

climate change

\section{Article History}

Received: 16 April 2018

Revised: 23 July 2018

Accepted: 1 August 2018

(c) The Author(s) 2018. This article is published with open access at link.Springer.com

\section{Introduction}

As reported by the International Energy Agency (IEA), the consumption of one-third of all energy and one-third of all $\mathrm{CO}_{2}$ emissions are attributable to the building sector (IEA 2013). De Wilde and Coley (2012) reported that the building sector is responsible for about $25-40 \%$ of greenhouse gas (GHG) emissions, which are the dominant driving factor for climate change. In addition, the global yearly-averaged air temperature is expected to increase by $1-2{ }^{\circ} \mathrm{C}$ by 2050 and $1.5-3.5{ }^{\circ} \mathrm{C}$ by 2085 (KNMI 2015). The rise of global yearly-averaged air temperature has implications for the energy demand of buildings (Chalmers 2014), peak energy use (Wang and Chen 2014), and related further consequences for GHG emissions (de Wilde and Coley 2012). Hence, increasing the energy efficiency of buildings by reducing the energy demand for heating and cooling, along with a consequent decrease of GHG emissions, is a crucial strategy to tackle climate change.

According to the Royal Netherlands Meteorological Institute (Koninklijk Nederlands Meteorologisch Instituut, KNMI), by 2050 a rise of the yearly-averaged air temperature between $1.0^{\circ} \mathrm{C}$ and $2.3{ }^{\circ} \mathrm{C}$ is expected in the Netherlands, compared to the reference period 1981-2010 (yearly average: $10.1^{\circ} \mathrm{C}$ ) (KNMI 2015). Furthermore, the KNMI predicts an increase of the yearly-averaged air temperature between $1.3^{\circ} \mathrm{C}$ and $3.7^{\circ} \mathrm{C}$ by 2085 , whereas in any future climate scenario minor changes are expected for the solar radiation (KNMI

E-mail: r.vasaturo@tue.nl 
2015). As a result, expected milder winters and warmer summers will lead to an increase of the cooling demand and, concurrently, a decrease of the heating demand. Although the energy demand for cooling of residential buildings is expected to increase globally (Arent et al. 2014; Chalmers 2014), in the Netherlands, so far, this increase has been modest (Itard and Meijer 2008; Fleiter et al. 2017). However, a market analysis conducted in 2000 reported that approximately 100,000 households in the Netherlands had an air conditioning system installed, and this number is expected to increase (van Kempen 2000). According to VHK (2008), air conditioning systems were installed in $6 \%$ of Dutch households in 2008, and the percentage will further increase to $8 \%$ in 2020 .

For the reasons stated above, limiting the energy demand for the current and in particular the future climate is an issue of great relevance. Many researchers have focused on the role of passive climate change adaptation measures to reduce heating and cooling demands in residential and non-residential buildings. Waddicor et al. (2016) performed BES to calculate the energy demand of a library building in Turin (Italy), applying different passive adaptation measures to reduce the cooling demand in current and future climate scenarios and taking into account the effect of ageing of the building. They achieved a maximum reduction in cooling demand of $87.3 \%$ by combining different passive measures, including a setpoint temperature of $28^{\circ} \mathrm{C}$ for air conditioning (based on Wan et al. 2012), lowering the values for the wall thermal transmittance $\left(U\right.$-value) to $0.6 \mathrm{~W} /\left(\mathrm{m}^{2} \cdot \mathrm{K}\right)$ and applying a solar heat gain coefficient for the windows of 0.16. Van Hooff et al. (2016) showed that, for a terraced house, applying natural ventilation and solar shading results in energy savings for cooling of respectively $59 \%$ and $74 \%$ compared to the case where no measures are applied. Pierangioli et al. (2017) examined the effects of several passive adaptation measures on three building types, two envelope types and three climate scenarios, i.e. the current climate (2000-2015) and two future climate scenarios (2036-2065 and 2066-2095) in Central Italy using building energy simulations (BES). They concluded that for highly insulated buildings the most effective way to limit the energy demand for heating and cooling is the adoption of night ventilation and solar shading; however, these measures were found to be only modestly effective for poorly insulated buildings. Huang and Hwang (2016) analyzed several passive climate change adaptation measures for three future climate scenarios (2020, 2050 and 2080) in Taiwan using BES, reporting that the best measure to limit the increase in cooling demand for the future climate scenarios consists in the application of higher thermal insulation values for the envelope, combined with a reduction of the solar heat gain coefficient of the windows and the application of overhangs for shading purposes. Invidiata and Ghisi (2016) investigated the effect of passive climate change adaptation measures on the energy consumption of a single-family house in three cities in Brazil for three future climate scenarios (2020, 2050 and 2080) using BES, concluding that an adequate combination of passive measures can reduce the total energy demand in terms of heating and cooling by up to $50 \%$ for the 2080 scenario compared to the case with no measures applied. Other BES studies focused on the impact of other building properties and/or passive adaptation measures on the energy performance of buildings, such as glazing type and window-to-wall ratio of the facades (e.g. Alghoul et al. 2017; Stevanović 2015), thermal mass (e.g. van Hooff et al. 2016; Reilly and Kinnane 2017; Sajjadian 2017), lighting load density (Wan et al. 2012), green roofs (Chan and Chow 2013; La Roche and Berardi 2014; van Hooff et al. 2016) and green facades (an extensive review of the potential energy savings of these systems is reported by Pérez et al. 2014), considering different climates and cities.

In addition, several BES studies focused on the adoption of passive climate change adaptation measures to reduce overheating in different building typologies. For instance, in the study by van Hooff et al. (2014) the use of passive technologies was analyzed as a measure to reduce the number of overheating hours for three building types in the Netherlands. They concluded that natural ventilation and exterior solar shading are the most effective measures to achieve this goal. Porritt et al. (2012) focused on the effect of several adaptation measures on the number of overheating hours for residential buildings. They reported that for a terraced house with a family occupancy profile the overheating hours can be reduced by $32 \%$ up to $100 \%$ (compared to the case with no measures applied) by adopting different combinations of passive measures, including night ventilation, increased wall albedo, solar shading devices and increased internal wall insulation. Ortiz et al. (2016) presented a costoptimal method to choose passive measures for the renovation of residential buildings in Catalonia (Spain) considering thermal comfort as one of the criteria. They indicated that properly combining passive measures can limit the number of overheating hours to less than $1 \%$ of the time.

Another important aspect to consider is the orientation of the building, which can greatly influence its energy demand (e.g. Pacheco et al. 2012) since it affects both the heat gain through the windows and the amount of light entering the building (e.g. Wong and Fan 2013). Previous studies showed the effect of the orientation on building heating and cooling demands (e.g. Abanda and Byers 2016; Aksoy and Inalli 2006; Carbonari et al. 2002; Gasparella et al. 2011; van Hooff et al. 2016; Jaber and Ajib 2011; Pino et al. 2012; Spanos et al. 2005; Susorova et al. 2013; Xu et al. 2012) and overheating hours (e.g. van Hooff et al. 2014; Porritt 
et al. 2012). Most of these studies focused on the combined impact of window-to-wall ratio, building shape and building orientation. Porritt et al. (2012) indicated that the building orientation plays an important role in overheating; indeed changes in the building orientation led to up to a $100 \%$ variation in terms of degree hours. Pino et al. (2012) estimated the impact of night ventilation, glazing type, window-to-wall ratio and orientation on the cooling demand of an office building in Santiago de Chile, finding that night ventilation could reduce cooling demands by up to $37 \%$. In the aforementioned studies by van Hooff et al. $(2014,2016)$ the impact of four building orientations on overheating hours and heating and cooling energy demands was estimated for the current climate (averaged over 1986-2005). They reported that the number of overheating hours for a terraced house can increase by up to $100 \%$ (compared to the minimum value) depending on the orientation adopted. In terms of energy demand, they found that for a residential building the orientation has a higher impact on cooling demand than on heating demand.

In conclusion, despite the increasing interest of researchers in evaluating the influence of passive climate change adaptation measures and building orientation on the energy demand of buildings, to the best of our knowledge none of the previous studies has assessed the effect of passive climate change adaptation measures and building orientation on heating and cooling demand for a detached, lightweight, semi-portable one-person residential building for current and future climate scenarios. This type of building, which has specific characteristics associated with its function, is thus considered in the present work, in which the aforementioned research gap is addressed using BES.

In Section 2 the setup of the building energy simulations is described. In Section 3 the results of the simulations considering different passive measures and orientations are presented for two EnergyPlus weather files (EPW): one is an EPW file for current climate, based on the period 19821999, whereas the other is based on a future climate scenario (2050). In Section 4 the results are discussed and in Section 5 conclusions and limitations of the present study are pointed out.

\section{Building energy simulations}

\subsection{Building geometry and simulation setup}

The design of the residential building considered for the BES simulations, performed using the software EnergyPlus (2010), is based on the Heijmans ONE building (Heijmans B.V. 2016). The Heijmans ONE building is a pre-fabricated, low-cost, one-person residence, currently commercialized by Heijmans B.V., a Netherlands-based construction services business. This building is targeting the temporary use of peripheral and derelict areas by single young professionals (25-35 years old) for a reasonable price (Heijmans B.V. 2018). It is designed to be semi-portable and semi-energy autarkic and therefore should be as energy efficient as possible. As shown in Fig. 1, a further peculiarity of this building is the extensive presence of glazing on the front facade and only a single window on the back facade, whereas no windows are present on the lateral (right and left) facades. As a consequence, the solar heat gain through the front facade is potentially higher than through the other facades and the energy demand might therefore be greatly influenced by the building orientation, which can change during the life cycle of the building due to its semi-portability. In Fig. 2, the floor plans and a vertical cross-section of the real building are displayed.

The building geometry used in BES is shown in Fig. 1. The total floor area of the building is $40.5 \mathrm{~m}^{2}$, of which $24.3 \mathrm{~m}^{2}$
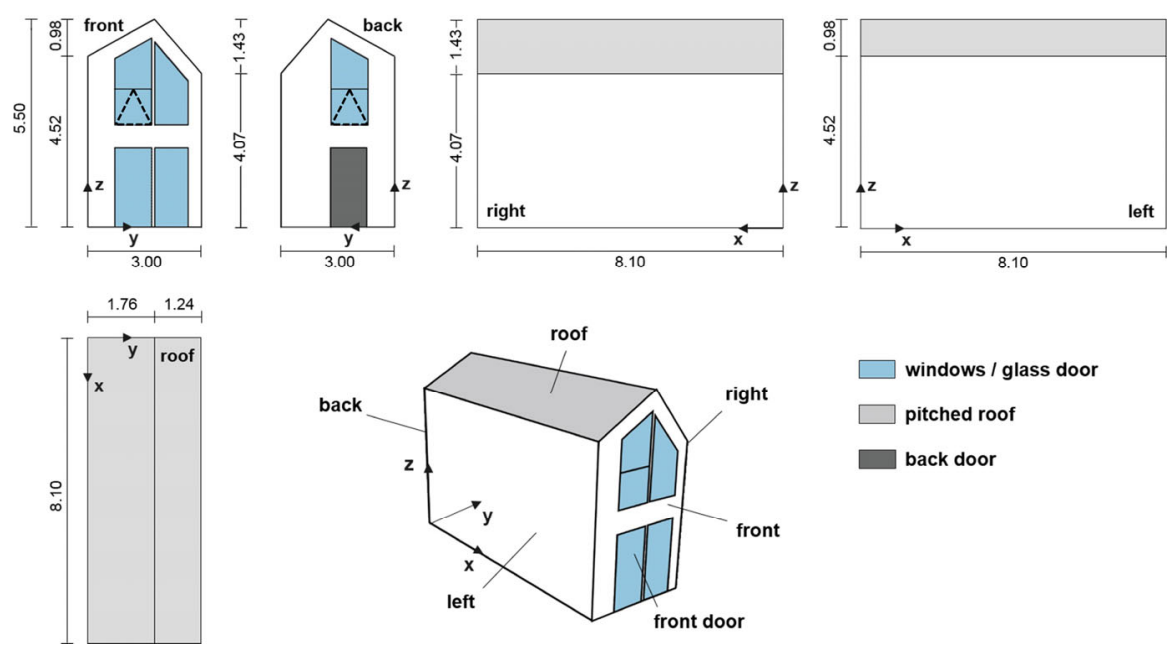

Fig. 1 Building geometry (dimensions in $\mathrm{m}$ ) 


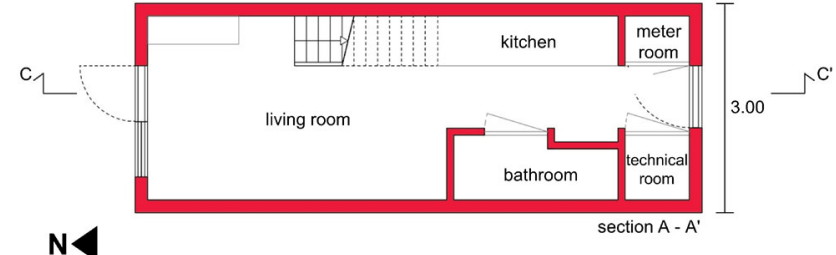

$\mathrm{N}$
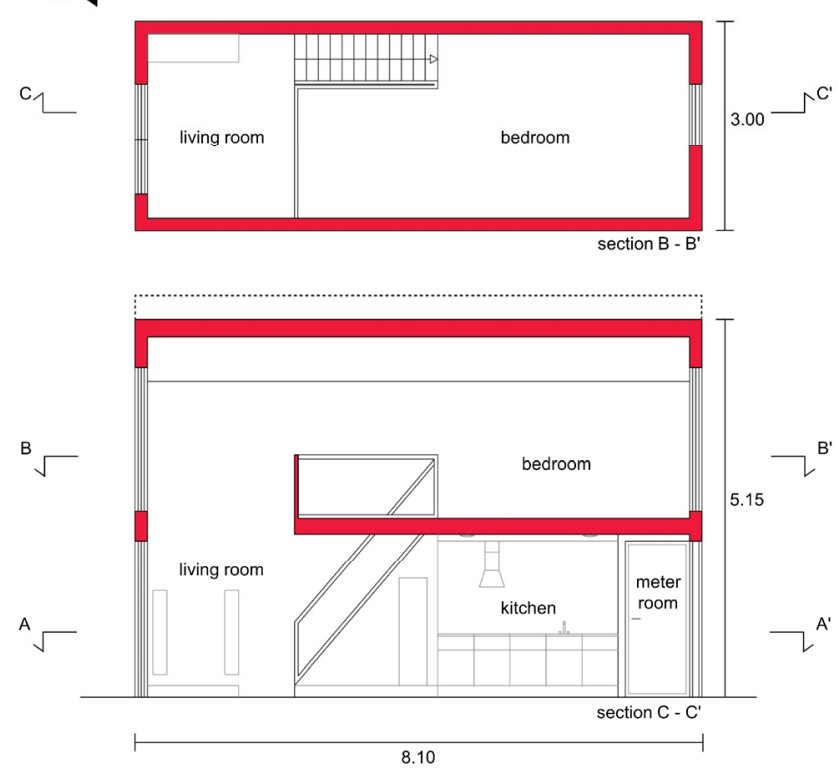

Fig. 2 Floor plans and vertical cross-section of the real building when oriented to the north (dimensions in $\mathrm{m}$ )

for the ground floor and $16.2 \mathrm{~m}^{2}$ for the first floor. The difference in floor area is due to a large open connection between both floors (Fig. 2). Because of this connection, the building can be regarded as a single-zone building. The construction details of the modeled building (Table 1) are based on the technical specifications of the real building (Heijmans B.V. 2016). Although Heijmans B.V. proposes three variations for the Heijmans ONE building (mainly differing in the number of solar panels, quality of appliances and finishing), a common layout, which is considered in the present paper, is assumed for all the three variations. The lateral facades and roof are modeled using steel cladding, an air cavity and two particleboard panels with an insulation layer between them. For front and back facades timber cladding is used instead of steel cladding. The insulation material is polyurethane foam (Heijmans B.V. 2016), the thickness of which is based on the thermal resistance value of the envelope $\left(R_{\mathrm{C}}=5.0 \mathrm{~m}^{2} \cdot \mathrm{K} / \mathrm{W}\right)$. The thermal conductivity $(\lambda)$ of the insulation material is assumed to be constant, although variations might actually occur as a function of temperature (e.g. Berardi et al. 2018). Since the variation of $\lambda$ is limited to $0.023-0.025 \mathrm{~W} /(\mathrm{m} \cdot \mathrm{K})$ for the insulation material and the temperature range of interest, $\lambda$ is set equal to $0.025 \mathrm{~W} /(\mathrm{m} \cdot \mathrm{K})$, i.e. the value at $24^{\circ} \mathrm{C}$ (ASHRAE 2001b). The thermal mass per visible surface area (floor, roof and walls) of the building is calculated according to the guidelines reported in ISSO (2011) and is $14 \mathrm{~kg} / \mathrm{m}^{2}$. This value is low enough to classify the building as lightweight $\left(<20 \mathrm{~kg} / \mathrm{m}^{2}\right.$; ISSO 2011). For the glass door and windows high performance low-emissivity glazing ( $\mathrm{HR}++, U \leq 1.2 \mathrm{~W} /\left(\mathrm{m}^{2} \cdot \mathrm{K}\right)$; Kiwa Nederland B.V. 2012) is used, which consists of double glazing. For this study $U=1.2 \mathrm{~W} /\left(\mathrm{m}^{2} \cdot \mathrm{K}\right)$ and a solar heat gain coefficient of 0.4 (Heijmans B.V. 2016) are chosen. The soil below the ground floor is modeled using a layer of sand of $1 \mathrm{~m}$ depth, at the bottom of which the temperature is set equal to $10^{\circ} \mathrm{C}$ (van Hooff et al. 2016); the shortwave reflectivity of the soil surrounding the building is taken equal to 0.2 .

The prescribed values for ventilation and infiltration rate are $0.9 \mathrm{dm}^{3} /\left(\mathrm{s} \cdot \mathrm{m}^{2}\right)$ and $0.2 \mathrm{~h}^{-1}$ air changes per hour $(\mathrm{ACH})$ respectively (Bouwbesluit 2012; ISSO 2011). The temperature setpoints for heating (Ministerie van VROM 2009) and cooling (ISSO 2011) are reported in Table 2. The heating, ventilation and air conditioning (HVAC) system is considered to be an ideal one, i.e. it supplies a sufficient amount of cooling or heating to maintain the desired zone temperature. Internal heat gains for appliances and lighting are set to $3.5 \mathrm{~W} / \mathrm{m}^{2}$, in accordance with the technical specifications of the building (Heijmans B.V. 2016). Electricity is used as energy source for the HVAC system and appliances. Heat gains due to the occupancy (by one person) are set according to the values indicated in ASHRAE (2009), i.e. $130 \mathrm{~W}$ between 18:00-23:00 h, $72 \mathrm{~W}$ between 23:00-06:00 $\mathrm{h}$ and no gain during working hours, i.e. $06: 00-18: 00 \mathrm{~h}$.

Table 1 Construction details for the base case

\begin{tabular}{|c|c|c|c|}
\hline Surface & Building components (outer to inner layer) & $R_{\mathrm{C}}\left[\mathrm{m}^{2} \cdot \mathrm{K} / \mathrm{W}\right]$ & $U\left[\mathrm{~W} /\left(\mathrm{m}^{2} \cdot \mathrm{K}\right)\right]$ \\
\hline $\begin{array}{l}\text { Lateral facades } \\
\text { and roof }\end{array}$ & $\begin{array}{l}\text { Steel cladding, air cavity, particleboard panel, insulation layer, } \\
\text { particleboard panel }\end{array}$ & 5.0 & - \\
\hline Front and back facades & $\begin{array}{l}\text { Timber cladding, air cavity, particleboard panel, insulation layer, } \\
\text { particleboard panel }\end{array}$ & 5.0 & - \\
\hline Floor & $\begin{array}{l}\text { Particleboard panel, insulation layer, } \\
\text { particleboard panel, PVC panel }\end{array}$ & 5.0 & - \\
\hline Windows, glass door & Low-emissivity glazing & - & 1.2 \\
\hline Back door & PVC panel, insulation layer, PVC panel & 0.9 & - \\
\hline
\end{tabular}


Table 2 Temperature setpoints for heating (Ministerie van VROM 2009) and cooling (ISSO 2011)

\begin{tabular}{cccc}
\hline Time & $6: 00-18: 00 \mathrm{~h}$ & $18: 00-23: 00 \mathrm{~h}$ & $23: 00-6: 00 \mathrm{~h}$ \\
\hline Heating setpoint & $19^{\circ} \mathrm{C}$ & $20^{\circ} \mathrm{C}$ & $16^{\circ} \mathrm{C}$ \\
Cooling setpoint & $24^{\circ} \mathrm{C}$ & $24^{\circ} \mathrm{C}$ & $24^{\circ} \mathrm{C}$ \\
\hline
\end{tabular}

TARP (Walton 1983) is adopted as indoor surface heat transfer convection algorithm, whereas for the exterior surfaces the correlations reported by Montazeri and Blocken (2017) are employed. The building energy simulations are performed using six time steps per hour, and 60 when employing green roofs, as recommended in the EnergyPlus Engineering Reference (EnergyPlus 2010).

Two climate scenarios are considered in the present work: one for the current and one for a future climate, in which the former refers to an EPW file based on the measured weather data in the years 1982-1999, whereas the latter refers to the year 2050. In both cases the chosen location is Beek, in the southeastern part of the Netherlands, because this town is located close (about $40 \mathrm{~km}$ ) to Weert (Netherlands), where the first Heijmans ONE buildings were installed. The corresponding climate zone according to Köppen and Geiger (1954) classification is temperate oceanic climate (Cfb), whereas according to ASHRAE (2013) it is cool humid (5A). The annual weather file for the current climate at this location spans an 18 years period of observation (1982-1999) and is included in the database 'International Weather for Energy Calculations' (IWEC; ASHRAE 2001a). For the future climate scenario the CCWorldWeatherGen (2013) tool of the University of Southampton is employed. This tool applies a morphing procedure to the current climate weather file to generate the EPW files for three climate scenarios: 2020, 2050 and 2080 . This procedure, reported by Jentsch et al. $(2008,2013)$ and also used by other researchers (e.g. Invidiata and Ghisi 2016; Kolokotroni et al. 2012; Yildiz et al. 2012), is based on the HadCM3 A2 experiment which was promoted by the International Panel for Climate Change (IPCC). As indicated in the CCWorldWeatherGen manual (2013), if the current climate weather file (i.e. the one used as input for the morphing procedure) is based on a time span which extends beyond the period of the HadCM3 experiment (1961-1990), the generated weather files for future climate scenarios might overestimate the effects of the climate change. For the present study the aforementioned EPW file for the current climate from IWEC (ASHRAE 2001a) is used as input for the CCWorldWeatherGen. The yearly-averaged temperature obtained for 2050 is $12.2^{\circ} \mathrm{C}$, which differs by only $0.1{ }^{\circ} \mathrm{C}$ from the ones determined by the KNMI (2015) in the $\mathrm{W}_{\mathrm{L}}$ and $\mathrm{W}_{\mathrm{H}}$ scenarios ('warm temperature rise'), which are respectively $12.1{ }^{\circ} \mathrm{C}$ and $12.3{ }^{\circ} \mathrm{C}$. Hence, although the EPW file used as input is based on the years 1982-1999 (rather than 1961-1990, as indicated in CCWorldWeatherGen manual), for the considered dataset there is no overestimation of the yearly-averaged temperature for 2050. In Fig. 3 the hourly and monthly-averaged dry-bulb temperature for both climate scenarios are reported. For the future climate scenario the monthly-averaged temperatures are higher in each month and the yearly-averaged temperature is $2.0^{\circ} \mathrm{C}$ higher than the current climate.

The building energy simulations, both for the case with no measures applied and the cases where passive adaptation measures are adopted, are performed considering eight building orientations (N, NE, E, SE, S, SW, W, NW) in order to: i) obtain more accurate averaged results (over the eight orientations considered), and ii) evaluate the impact of building orientation. The results of the simulations are presented in terms of annual heating, cooling and total (heating and cooling) energy demand for the building considered, expressed in $\mathrm{kWh}$ per $\mathrm{m}^{2}$ floor area.

(a)

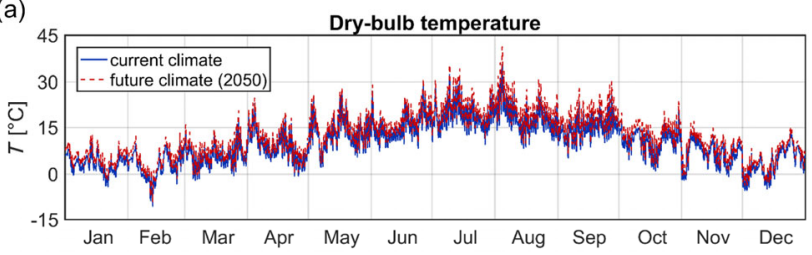

(b)

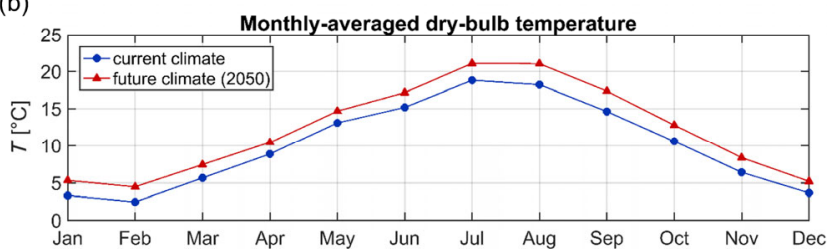

Fig. 3 (a) Hourly and (b) monthly-averaged dry-bulb temperature for current EnergyPlus (2010) and future climate (2050)

\subsection{Passive climate adaptation measures}

\section{Base case}

For the base case (BC), i.e. the case where no adaptation measures are applied to the building, the emissivity of all the building surfaces is set to 0.9 , the shortwave reflectivity (albedo, $\alpha$ ) is set to $\alpha=0.3$ (Chin et al. 2014) for roof and lateral facades, and to $\alpha=0.4$ for front and back facades (Bretz et al. 1992). In addition, no solar shading system is adopted and no natural ventilation is allowed. Finally, as mentioned in Section 2.1, a thermal resistance value of $R_{\mathrm{C}}=$ $5.0 \mathrm{~m}^{2} \cdot \mathrm{K} / \mathrm{W}$ is used for the building envelope (Heijmans B.V. 2016).

\section{Roofs and walls with high shortwave reflectivity}

The first adaptation measure considered consists in employing 
roofs and walls with a higher shortwave reflectivity than conventional construction materials. Experimental and numerical studies (e.g. Akbari et al. 1997; Synnefa et al. 2007,2012 ) showed that the building cooling demand can be decreased significantly when increasing the roof albedo. Santamouris (2014) reported that variations in cooling energy reduction are attributable to weather conditions and building features (e.g. building typology and insulation values) and that a typical potential reduction of peak temperature by up to $2{ }^{\circ} \mathrm{C}$ can be obtained for moderately insulated buildings, with a corresponding decrease in the cooling demand by $10 \%$ to $40 \%$. Bretz and Akbari (1997) showed a potential decrease of the cooling demand (up to $70 \%)$ using high-albedo roofs ( $\alpha=0.5-0.8)$. In conclusion, increasing the surface albedo can be an effective solution to improve the performance of a building in terms of cooling energy demand and thermal comfort (Synnefa et al. 2007).

In the present work, the shortwave reflectivity of the roof, and subsequently roof and walls, is increased to $\alpha=$ 0.7 when applying this adaptation measure.

\section{Solar shading}

A commonly adopted passive measure is the application of solar shading to the transparent parts of the envelope, in this case glass door and windows. This measure is expected to be particularly effective for the building under examination, which has a high thermal resistance and a large concentration of glazing on a single facade. Solar shading systems can be classified as fixed and movable; the former can be external or internal, whereas the latter can be external, internal or intermediate (e.g. Bellia et al. 2014). The advantage of exterior shading over interior shading is that it is more effective, since it prevents solar radiation from entering the building through the transparent surfaces.

An automated movable exterior solar shading system is considered in the present study. For the activation of this system, two conditions need to be satisfied (Table 3): the first one is that the incident solar radiation, $Q_{\text {in }}$, is higher than $150 \mathrm{~W} / \mathrm{m}^{2}$ (van Hooff et al. 2016; Zhang and Barrett 2012); the second one is that the indoor air temperature, $T_{\text {zone }}$, is higher than $21^{\circ} \mathrm{C}$ (van Hooff et al. 2016). Setting the double threshold (minimum indoor air temperature and maximum incident solar radiation) allows for an optimal use of the solar radiation. During the winter, the entering

Table 3 Conditions for exterior solar shading and natural ventilation

\begin{tabular}{lcc}
\hline & \multicolumn{2}{c}{ Time } \\
\cline { 2 - 3 } & $8: 00-20: 00 \mathrm{~h}$ & $20: 00-8: 00 \mathrm{~h}$ \\
\hline Exterior solar shading & $T_{\text {zone }}>21^{\circ} \mathrm{C}$ and $Q_{\text {in }}>150 \mathrm{~W} / \mathrm{m}^{2}$ \\
Natural ventilation & $T_{\text {zone }}>23^{\circ} \mathrm{C}$ and $T_{\text {out }}<T_{\text {zone }}$ & Windows closed \\
\hline
\end{tabular}

solar radiation reduces the amount of heating needed to reach the temperature setpoints. On the other hand, during the summer, when both temperature and incident radiation are above the threshold values, the shading system is active, thus preventing the indoor temperature to rapidly increase over $T=24^{\circ} \mathrm{C}$, i.e. the setpoint above which the cooling system is active (Table 2). The implementation of the control logic in EnergyPlus is straightforward: the abovementioned double threshold is set and the desired values of incident solar radiation and minimum indoor temperature are specified. Once these conditions are met, the exterior solar shading is activated.

\section{Green roofs}

Green roofs are non-conventional roofs, made of a waterproof membrane, a growing medium and vegetation on the top. Several reviews were published on green roofs in the past (e.g. Berardi et al. 2014; Saadatian et al. 2013; Santamouris 2014; Sproul et al. 2014). Using green roofs may decrease the total energy demand by up to $40 \%$ depending on the types of roof, building and climate considered (Santamouris 2014). Variations in the performance of green roofs are due to soil and vegetation characteristics, such as the leaf area index (LAI) - defined as the functional leaf area $\left(\mathrm{m}^{2}\right)$ per unit ground surface area $\left(\mathrm{m}^{2}\right)$-, local climate and building characteristics (e.g. thermal insulation value). Another important advantage is the potential, when applied on city scale, for decreasing the temperature in the city during heat waves, especially if the UHI effect is present (e.g. Coutts et al. 2013; Kolokotsa et al. 2013; Santamouris 2014; Susca et al. 2011). Local application only however was shown to have negligible effect on outdoor air temperature (Gromke et al. 2015). Aesthetic impact (e.g. Berardi et al. 2014; Sproul et al. 2014), increased durability of the roof (e.g. Santamouris 2014), but also the higher initial cost compared to a standard roof (e.g. Saadatian et al. 2013) are additional aspects to take into account.

In the present work a green roof with a LAI equal to 5 is considered, with a plant height of $0.1 \mathrm{~m}$, following the previous work of van Hooff et al. $(2014,2016)$. This choice classifies the adopted green roof as extensive green roof (Gaffin et al. 2009).

\section{Thermal resistance}

According to the Dutch building code (Bouwbesluit 2012), the $R_{\mathrm{C}}$ of the non-transparent parts of the envelope needed to be higher than $3.5 \mathrm{~m}^{2} \cdot \mathrm{K} / \mathrm{W}$ during the execution of this research. As previously mentioned, the $R_{\mathrm{C}}$ value for the base case is $5.0 \mathrm{~m}^{2} \cdot \mathrm{K} / \mathrm{W}$. An increase of the $R_{\mathrm{C}}$ to $6.5 \mathrm{~m}^{2} \cdot \mathrm{K} / \mathrm{W}$ is considered as a possible adaptation measure. In order to increase $R_{\mathrm{C}}$, the thickness of the insulation layer is increased. 


\section{Natural ventilation}

An important and simple method to reduce the cooling demand and ensure that fresh air can enter the building is natural ventilation (e.g. van Hooff et al. 2016; Pierangioli et al. 2017; Pino et al. 2012; Wang and Chen 2014). Differently from the base case, where the windows remain closed during the entire day, they are allowed to be opened for natural ventilation purposes in the case where this measure is applied. The openable windows are indicated in Fig. 1 by dashed triangles. Since issues with security, outdoor sound levels, insects and rain penetration (e.g. van Hooff et al. 2014) might prevent the occupants to open the windows during the night, the time during which windows can be opened is limited 8:00-20:00 h. Furthermore, a double threshold is set as a condition to open the windows (Table 3): i) $T_{\text {zone }}>23{ }^{\circ} \mathrm{C}$, so that natural ventilation is active before the air conditioning system and ii) $T_{\text {out }}<T_{\text {zone }}$, to ascertain that cooler air is provided by the external environment to the interior. When the threshold for air conditioning is reached (Table 2) and the criteria for natural ventilation (Table 3 ) are also met, both contribute to reduce the indoor temperature. However, for the case considered in the present study, air conditioning and natural ventilation are active at the same time only for a limited number of hours during the year, whereas in the most of the remaining time in which cooling is needed exclusively one of the two systems is active because $T_{\text {out }}>T_{\text {zone }}>24^{\circ} \mathrm{C}$ (only air conditioning is active) or $23{ }^{\circ} \mathrm{C}<T_{\text {zone }}<24^{\circ} \mathrm{C}$ and $T_{\text {out }}<T_{\text {zone }}$ (only natural ventilation is active)

\section{Results}

\subsection{Impact of the future climate on the energy demand}

The yearly-averaged heating and cooling demands for the base case are presented in Fig. 4 for the current and future climate, which are obtained by averaging over all eight orientations. In 2050 a significant decrease of the heating demand is predicted ( $-23 \%$, from 109.8 to $85.0 \mathrm{kWh} / \mathrm{m}^{2}$ ) due to higher winter temperatures (Fig. 3) compared to the current climate. On the other hand, a strong increase of energy demand for cooling is predicted; specifically, it is expected to increase by $118 \%$ (from 8.6 to $18.7 \mathrm{kWh} / \mathrm{m}^{2}$ ), i.e. it is more than double compared to the current climate. This can be attributed to the predicted higher temperatures in the future climate compared to the current climate, especially in the summer period.

The resulting ratios of heating/cooling demand are 12.8 for the current climate and 4.5 for the future climate. For the future climate the absolute reduction of heating demand is larger than the increase of cooling demand, resulting in a net reduction of $14.7 \mathrm{kWh} / \mathrm{m}^{2}(-12 \%)$ of the total energy demand for heating and cooling (Table 4). This is in line with previous findings of van Hooff et al. (2016), who reported a reduction of the annual energy demand of approximately $8 \%$ for the residential building they studied.

\subsection{Impact of passive climate adaptation measures on the energy demand}

The impact of the different passive adaptation measures is evaluated by comparing the predicted energy demands with the base case (BC), where no measures are applied. Figures 5-6 show heating and cooling demands - averaged over eight orientations - obtained by employing different measures: high shortwave reflectivity roof and walls (SWR_RW), high shortwave reflectivity roof (SWR_R), exterior solar shading (SS), green roof (GR), increased thermal resistance (TR) of the non-transparent parts of the building envelope, daily natural ventilation (NV), and combined solar shading and increased thermal resistance (SS + TR).

Most of the passive measures applied to the building have a small effect on the heating demand (Fig. 5), except for the application of a higher $R_{\mathrm{C}}$ to the non-transparent parts of the building envelope (TR), which results in about $8 \%$ energy savings for heating due to reduced heat transfer from the interior to the exterior. The application of higher albedo for roofs and walls (SWR_RW) results in an increase of 3\% due to the fact that a higher surface albedo entails a higher reflection of the shortwave solar radiation on the building envelope, thus resulting in lower heat gains and therefore a higher heating demand.

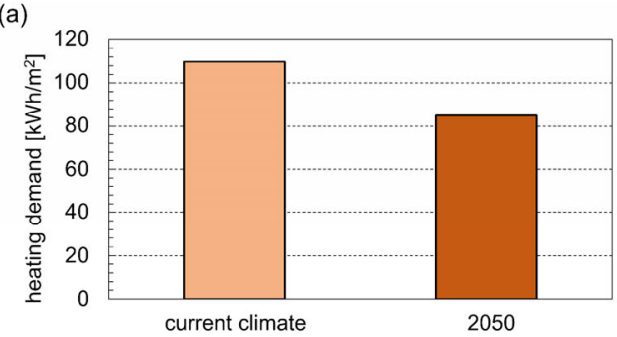

(b)

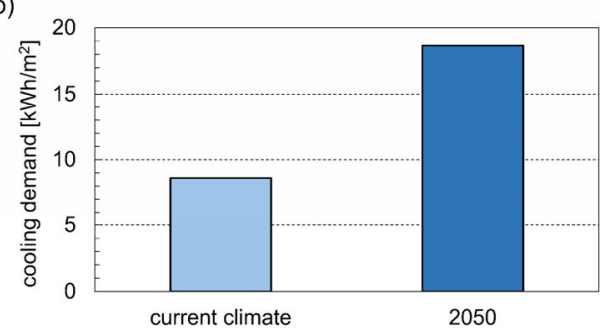

Fig. 4 Annual energy demand averaged over eight orientations for the base case for (a) heating and (b) cooling for current and future climate (2050) 
Table 4 Impact of passive adaptation measures on total (heating and cooling) energy demand. Results are averaged over eight orientations. Legend: BC - base case; SWR_RW - high shortwave reflectivity roof and walls; SWR_R - high shortwave reflectivity roof; SS - exterior solar shading; GR - green roof; TR - higher $R_{\mathrm{C}} ; \mathrm{NV}$ - natural ventilation; $\mathrm{SS}+\mathrm{TR}$ - exterior solar shading + higher $R_{\mathrm{C}}$

\begin{tabular}{ccccc}
\hline \multirow{2}{*}{$\begin{array}{c}\text { Adaptation } \\
\text { measure }\end{array}$} & \multicolumn{2}{c}{ Current climate } & \multicolumn{3}{c}{ Future climate (2050) } \\
\cline { 2 - 3 } \cline { 5 - 5 }$\left[\begin{array}{c}\text { Total demand } \\
{\left[\mathrm{kWh} / \mathrm{m}^{2}\right]}\end{array}\right.$ & $\Delta$ & $\begin{array}{c}\text { Total demand } \\
{\left[\mathrm{kWh} / \mathrm{m}^{2}\right]}\end{array}$ & $\Delta$ \\
\hline BC (ref.) & 118.4 & - & 103.7 & - \\
SWR_RW & 119.7 & $+1 \%$ & 103.1 & $|\Delta|<1 \%$ \\
SWR_R & 118.5 & $|\Delta|<1 \%$ & 103.3 & $|\Delta|<1 \%$ \\
SS & 114.0 & $-4 \%$ & 95.4 & $-8 \%$ \\
GR & 117.2 & $-1 \%$ & 102.2 & $-1 \%$ \\
TR & 109.7 & $-7 \%$ & 96.8 & $-7 \%$ \\
NV & 116.6 & $-2 \%$ & 101.8 & $-2 \%$ \\
SS + TR & 105.2 & $-11 \%$ & 88.3 & $-15 \%$ \\
\hline
\end{tabular}

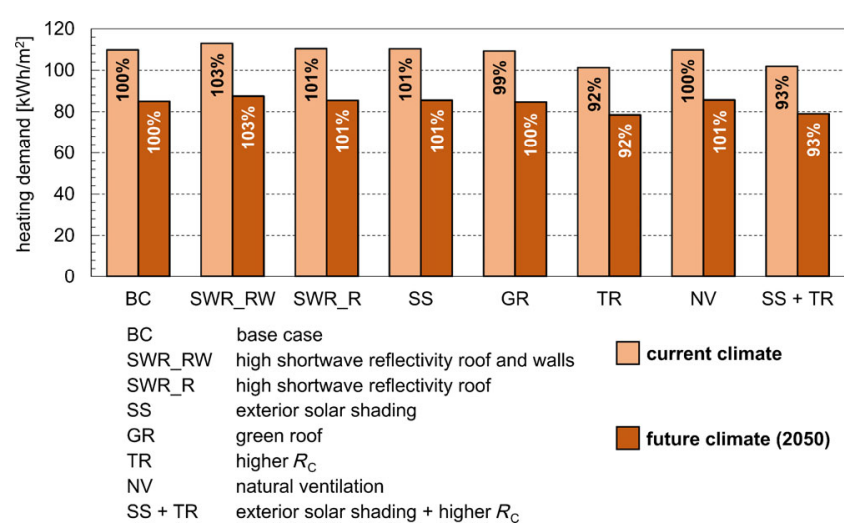

Fig. 5 Annual heating energy demand for current and future climate considering the application of passive adaptation measures. Results are averaged over eight orientations

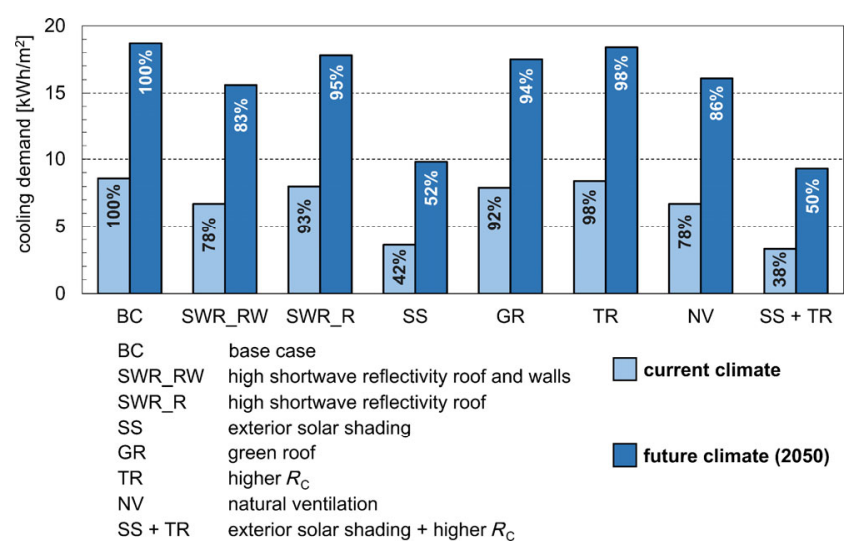

Fig. 6 Annual cooling energy demand for current and future climate considering the application of passive adaptation measures. Results are averaged over eight orientations

In terms of cooling demand (Fig. 6), larger differences are present when different adaptation measures are applied.
Increasing the roof albedo (SWR_R) reduces the cooling demand by $7 \%$ and $5 \%$ for the current and future climate, respectively, while increasing also the albedo of the walls (SWR_RW) leads to a decrease of the cooling demand of $22 \%$ and $17 \%$. The application of SS leads to the largest reduction in cooling demand, i.e. $-58 \%\left(-5.0 \mathrm{kWh} / \mathrm{m}^{2}\right)$ for the current climate and $-48 \%\left(-8.9 \mathrm{kWh} / \mathrm{m}^{2}\right)$ for the future climate. Applying a GR to the building results in a similar performance as SWR_R with respect to the cooling demand. Increasing TR leads to modest reductions in cooling demand. Applying daily NV results in a reduction of cooling demand of $22 \%$ for the current climate and $14 \%$ for the future climate.

When the total energy demand for heating and cooling averaged over eight orientations - is considered (Table 4), applying SWR_R or SWR_RW results in an overall modest change of the total energy demand for both climate scenarios because the reduction in cooling demand is compensated by a higher heating demand. Similarly, the application of GR as adaptation measure leads to small savings in terms of total demand. Employing SS strongly reduces cooling demands, but has a minimal impact on the heating demand (about 1\%) due to the adopted thresholds (Table 3), which allow solar radiation to enter the building when the indoor temperature and/or the incident solar radiation are sufficiently low. The resulting total energy demand reduction for SS amounts to $4 \%$ for the current climate and $8 \%$ for the future climate. In the latter case the impact of the SS on the total energy demand is larger due to the higher contribution of the cooling demand to the total energy demand for the future climate (18\%) compared to the current climate (7\%). Increasing the thermal resistance (TR) reduces the total energy demand by $7 \%$ for both the current and future climate scenarios, mainly because of the reduction in heating demand (Fig. 5). NV has only a modest impact on the total energy demand, which is reduced by about $2 \%$ for both climate scenarios, since this measure barely affects the heating demand (which represents most of the yearly energy demand).

Finally, a best case is proposed, consisting in the application of exterior solar shading and increased thermal resistance (SS + TR). In this way, a reduced cooling demand, mainly due to the application of the exterior solar shading, and a reduced heating demand, due to the higher thermal resistance, are obtained when considering the average over eight orientations. Specifically, heating demands are reduced by $7 \%$ for both climate scenarios, while cooling demands are significantly reduced by $62 \%$ and $50 \%$ for current and future climate, respectively. As reported in Table 4, this solution would result in total energy savings of $11 \%$ $\left(13.2 \mathrm{kWh} / \mathrm{m}^{2}\right)$ for the current climate and $15 \%\left(15.4 \mathrm{kWh} / \mathrm{m}^{2}\right)$ 
for the future climate scenario compared to the respective base cases.

\subsection{Impact of orientation on energy demand}

For all the cases analyzed, the building is considered, for example, to be oriented to the north when the front facade faces the geographical north (Fig. 2). The two important factors in this analysis are: i) the orientation of the building, which determines the position of glazing and therefore the amount of heat gains through the transparent surfaces; ii) the position of the sun, in particular the solar elevation angle, defined as the angle between the horizon and the solar disc, which depends on the time of day and the period of the year.

The annual energy demands for heating and cooling as a function of the building orientation are reported in Table 5 and are depicted by means of radial plots in Figs. 7-8. Considering the current climate scenario, the highest heating demand is obtained when the building faces $\mathrm{N}$ and NW $\left(113.2 \mathrm{kWh} / \mathrm{m}^{2}\right.$ for both cases, $+3.2 \%$ compared to the average over the eight orientations considered) due to a reduced heat gain through the transparent surfaces (i.e. glass door and windows). The minimum occurs when the building is oriented towards $\mathrm{S}\left(104.0 \mathrm{kWh} / \mathrm{m}^{2},-5.2 \%\right)$, for which the abovementioned heat gain is maximized. Specifically, for the current climate the heat gain through the transparent surfaces (including both the solar heat gain and the energy absorbed by convection) amounts to $1595 \mathrm{kWh}\left(39.4 \mathrm{kWh} / \mathrm{m}^{2}\right)$ per year when the building faces $\mathrm{S}$, whereas it is reduced to $879 \mathrm{kWh}\left(21.7 \mathrm{kWh} / \mathrm{m}^{2}\right)$ per year when the building faces N. Similar results in terms of heating demand are obtained for the future climate (Table 5).

In terms of cooling demand the highest value for the current climate occurs when the building faces SW $\left(10.5 \mathrm{kWh} / \mathrm{m}^{2},+22.5 \%\right)$ and the lowest one when the building faces $\mathrm{N}\left(5.9 \mathrm{kWh} / \mathrm{m}^{2},-31.0 \%\right)$. Similar differences are obtained for the future climate. Hence, in both scenarios orienting the building towards N, NE or NW results in a higher energy demand for heating compared to the other orientations; on the other hand, these orientations appear to be the most convenient in terms of cooling energy demand. The reason for this behavior is the same: when the building faces N, NE or NW, solar heat gain through the transparent parts of the envelope is minimized. N, NE and NW orientations are therefore advantageous in terms of cooling demand and disadvantageous in terms of heating demand. For the same reason the highest cooling demands are obtained when the building faces SW and, secondarily, SE. In these two cases the solar radiation enters the building through the window on the back facade (oriented towards $\mathrm{NE}$ and NW, respectively) in the early morning (SW orientation) or evening (SE orientation) during the summer, and through the windows on the front facade during the rest of daytime, especially before (SE orientation) or after (SW orientation) noon, when the solar inclination is lower than at noon but the amount of incident solar radiation is comparable. For this reason the predicted cooling demands for SW and SE orientations are higher than the one obtained for the S orientation.

The impact of the orientation on the total energy demand for the current and the future climate is reported in Fig. 9. For both climate scenarios the lowest energy demand is obtained when the building is oriented towards $\mathrm{S}$ $(-4.4 \%$ and $-2.9 \%$ for current and future climate, respectively) which, as discussed above, is also the orientation that gives the lowest heating energy demand. The highest total energy demand is predicted for a NW oriented building for the current climate $\left(120.5 \mathrm{kWh} / \mathrm{m}^{2}\right)$ and $\mathrm{W}$ oriented building for the future climate $\left(106.1 \mathrm{kWh} / \mathrm{m}^{2}\right)$. The prevailing factor for limiting the total (heating + cooling) energy demand of the building is the reduction of the heating

Table 5 Impact of building orientation on heating and cooling demand for the sase case in current and future climate scenarios. Average values over eight orientations are taken as reference

\begin{tabular}{ccccc}
\hline & \multicolumn{3}{c}{ Climate scenario } \\
\cline { 2 - 5 } Building orientation & Heating demand & Cooling demand & Heating demand & Cooling demand \\
\cline { 2 - 5 } Reference value & $109.8 \mathrm{kWh} / \mathrm{m}^{2}$ & $8.6 \mathrm{kWh} / \mathrm{m}^{2}$ & $85.0 \mathrm{kWh} / \mathrm{m}^{2}$ & $18.7 \mathrm{kWh} / \mathrm{m}^{2}$ \\
$\mathrm{~N}$ & $+3.2 \%$ & $-31.0 \%$ & $+3.1 \%$ & $-24.3 \%$ \\
$\mathrm{NE}$ & $+2.9 \%$ & $-16.9 \%$ & $+3.0 \%$ & $-14.3 \%$ \\
$\mathrm{E}$ & $+1.0 \%$ & $+6.7 \%$ & $+0.9 \%$ & $+4.5 \%$ \\
$\mathrm{SE}$ & $-2.7 \%$ & $+15.3 \%$ & $-2.9 \%$ & $+13.2 \%$ \\
$\mathrm{~S}$ & $-5.2 \%$ & $+5.2 \%$ & $-5.3 \%$ & $+7.8 \%$ \\
$\mathrm{SW}$ & $-3.1 \%$ & $+22.5 \%$ & $-3.0 \%$ & $+17.5 \%$ \\
$\mathrm{~W}$ & $+0.8 \%$ & $+13.3 \%$ & $+1.0 \%$ & $+8.6 \%$ \\
$\mathrm{NW}$ & $+3.2 \%$ & $-15.2 \%$ & $+3.2 \%$ & $-13.0 \%$ \\
\hline
\end{tabular}


(a)

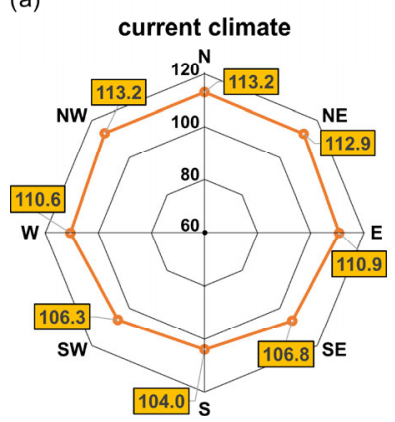

(b)

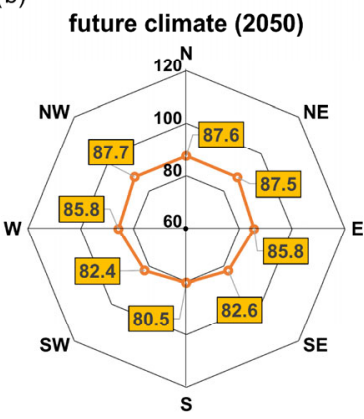

Fig. 7 Annual heating energy demand (in $\mathrm{kWh} / \mathrm{m}^{2}$ ) for the base case for (a) current and (b) future climate. Average values over eight orientations are $109.8 \mathrm{kWh} / \mathrm{m}^{2}$ and $85.0 \mathrm{kWh} / \mathrm{m}^{2}$ for (a) and (b), respectively

(a)

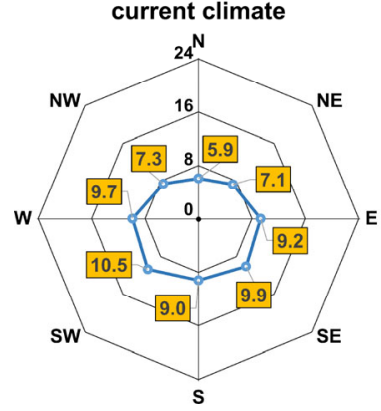

(b)

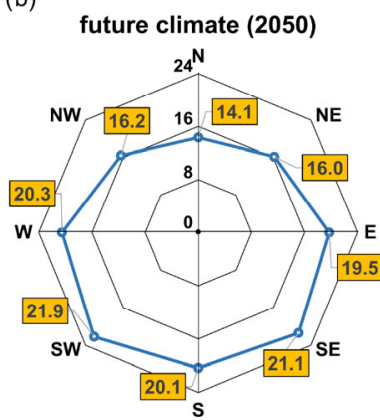

Fig. 8 Annual cooling energy demand (in $\mathrm{kWh} / \mathrm{m}^{2}$ ) for the base case for (a) current and (b) future climate. Average values over eight orientations are $8.6 \mathrm{kWh} / \mathrm{m}^{2}$ and $18.7 \mathrm{kWh} / \mathrm{m}^{2}$ for (a) and (b), respectively

(a)

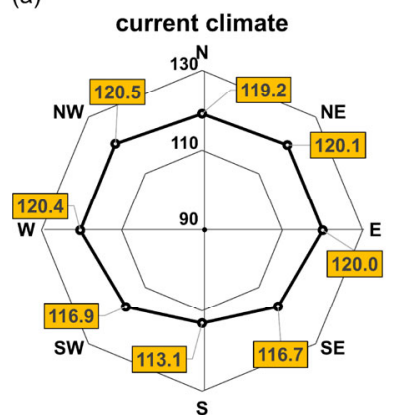

(b)

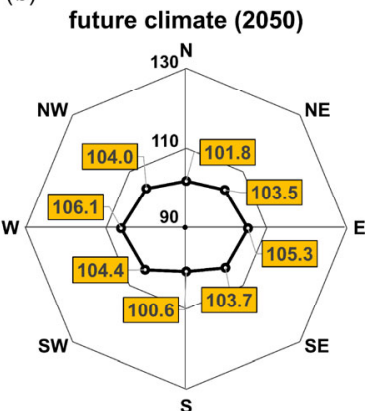

Fig. 9 Annual total (heating and cooling) energy demand (in $\mathrm{kWh} / \mathrm{m}^{2}$ ) for the base case for (a) current and (b) future climate. Average values over eight orientations are $118.4 \mathrm{kWh} / \mathrm{m}^{2}$ and 103.7 kWh/ $\mathrm{m}^{2}$ for (a) and (b), respectively

demand, which represents the largest part of the energy demand for both climate scenarios (Table 5).

In Fig. 10 the cooling demand as a function of the orientation is shown for the best case discussed in Section 3.2, i.e. where SS + TR are applied. The results displayed in this figure indicate that preventing the solar radiation from entering the building (when the conditions in Table 3 are met) limits the dependence of the cooling demand on

the orientation, since orientation determines the solar heat gain. Specifically, the cooling load varies between 3.1 and $3.6 \mathrm{kWh} / \mathrm{m}^{2}$ for the current climate and between 8.9 and $9.9 \mathrm{kWh} / \mathrm{m}^{2}$ for the future climate. Note that the cooling demand is higher for the north-oriented facade due to the lower reduction of heat gain through the transparent surfaces (with respect to the base case) compared to the other orientations; for example, a reduction of $3.5 \mathrm{kWh} / \mathrm{m}^{2}$ when the building faces $\mathrm{N}$ and $10.3 \mathrm{kWh} / \mathrm{m}^{2}$ when it faces $\mathrm{S}$ are predicted. With respect to the heating demand, it has already been shown (Fig. 5) and discussed (Section 3.2) that solar shading has a very limited effect on the heating demand. Finally, in Fig. 11 the impact of orientation on the total energy demand for the case where SS + TR are applied is reported. Since, as previously discussed, exterior solar shading reduces the effects of orientation on the cooling demand, the dominant factor for the reduction of the total energy demand is the reduction of the heating demand. The total energy demand is thus minimized when the building faces $\mathrm{S}\left(99.6 \mathrm{kWh} / \mathrm{m}^{2}\right.$ and $83.7 \mathrm{kWh} / \mathrm{m}^{2}$ for the current and future
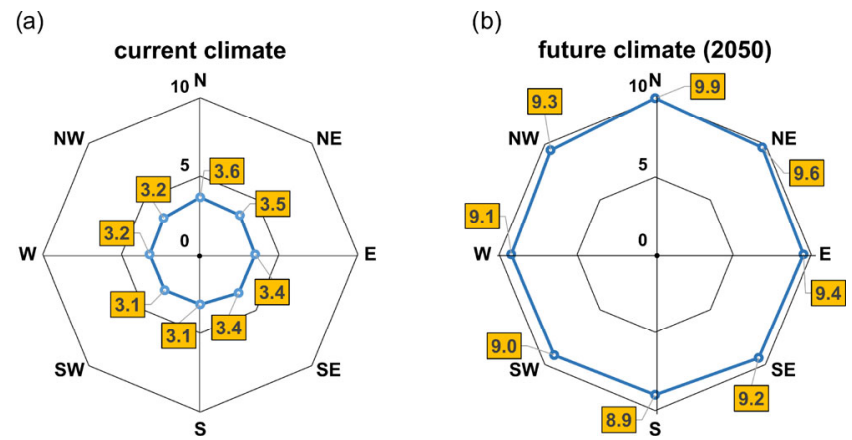

Fig. 10 Annual cooling energy demand (in $\mathrm{kWh} / \mathrm{m}^{2}$ ) for (a) current and (b) future climate for the case with exterior solar shading and increased thermal resistance applied (SS + TR). Average values over eight orientations are $3.3 \mathrm{kWh} / \mathrm{m}^{2}$ and $9.3 \mathrm{kWh} / \mathrm{m}^{2}$ for (a) and (b), respectively (a)

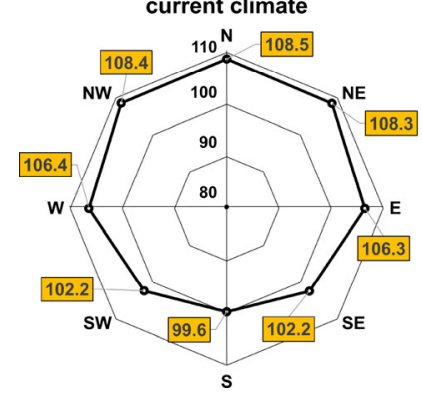

(b)

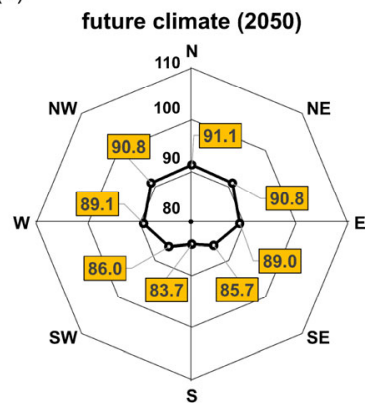

Fig. 11 Annual total (heating and cooling) energy demand (in $\mathrm{kWh} / \mathrm{m}^{2}$ ) for (a) current and (b) future climate for the case with exterior solar shading and increased thermal resistance applied (SS + TR). Average values over eight orientations are $105.2 \mathrm{kWh} / \mathrm{m}^{2}$ and $88.3 \mathrm{kWh} / \mathrm{m}^{2}$ for (a) and (b), respectively 
climate, respectively) primarily because for this orientation the heating demand is minimized and, less importantly, the cooling demand is also minimized.

\section{Discussion}

\subsection{Passive adaptation measures}

Several factors must be taken into account when implementing passive adaptation measures to decrease the building energy demand for heating and cooling for a detached lightweight semi-portable building operating in the considered location (southeastern part of the Netherlands) and climate scenarios. First of all, as shown in Section 3.2, increasing the roof albedo (SWR_R) or both the albedo of the roof and walls (SWR_RW) reduces the cooling demand, while the heating demand is increased. For the current climate more drawbacks than advantages arise when adopting SWR_R or SWR_RW; in contrast, given the lower ratio of heating/cooling energy demand, for the future climate these measures produce a very limited but positive effect (Table 4). Application of a green roof (GR) to the considered building leads to small total energy reductions in both climate scenarios, but the needed structural changes (for instance due to the irrigation system and the additional roof load) and the high maintenance costs for this type of roof (e.g. Sproul et al. 2014), neither of which are considered in the present analysis, would make the choice for a GR less straightforward in practice. Using natural ventilation $(\mathrm{NV})$ can be a cheap and effective solution for the type of building and climate considered; nevertheless, the effectiveness of this passive measure is greatly influenced by the occupant, who is required to open and close the windows when needed, unless this is automated. Increasing the thermal resistance (TR) of the envelope of the lightweight building under investigation is an effective measure to considerably limit the heating demand and, to a lesser extent, the cooling demand. The latter aspect depends on the thermal mass of the building and the internal and solar heat gains (size and orientation of windows). In previous studies (e.g. Aebischer et al. 2007; van Hooff et al. 2016), it was reported that an increase of the thermal resistance results in an increase of the cooling demand. For example, van Hooff et al. (2016) reported that once the solar radiation enters the building through the transparent surfaces, the reduced heat transfer from indoor to outdoor through the building envelope leads to a higher indoor temperature, and thus higher cooling energy demand. For the case under examination two elements contribute to an opposite trend for the cooling demand, i.e. that increased thermal resistance leads to a reduction of the cooling demand. The first one is the type of glazing employed for this building, low-emissivity glass with a solar heat gain coefficient of 0.4 , which reduces the solar heat gain through windows and glass door. The second factor is the role played by the thermal mass; the building in the current study is classified as a lightweight building (Section 2.1). Further simulations (not reported) have been performed for the base case (BC) configuration, but replacing the inner layer of particleboard with limestone in order to double the thermal mass of the entire building (from $14 \mathrm{~kg} / \mathrm{m}^{2}$ to $28 \mathrm{~kg} / \mathrm{m}^{2}$ ). In this case the behavior described, for example, by Aebischer et al. (2007) and van Hooff et al. (2016) is retrieved, giving rise to an increase of the energy demand for cooling $(+4 \%)$ when increasing the thermal resistance from $R_{\mathrm{C}}=5.0 \mathrm{~m}^{2} \cdot \mathrm{K} / \mathrm{W}$ to $R_{\mathrm{C}}=6.5 \mathrm{~m}^{2} \cdot \mathrm{K} / \mathrm{W}$. Hence, variations in the thermal mass (low/high) of the building can change the trend (decreasing/increasing) of the cooling demand when increasing the thermal resistance of the envelope. The most effective single measure for the building considered in the present paper, also in terms of installation and maintenance costs, consists in adopting exterior solar shading (SS), whose efficiency (unless automated) is however also subjected to occupant behavior. In conclusion, adopting a combination of SS and TR is the most effective solution among those considered in the present study to reduce cooling and heating demand for a detached, lightweight, semi-portable one-person house for both climate scenarios, resulting in reductions of $11 \%$ and $15 \%$ of total energy demand for the current and future climates, respectively, compared to the respective base cases.

\subsection{Role of the orientation on the energy demand}

Considering the case where no adaptation measures are applied (BC), the lowest heating demand - as to be expected - is obtained when the building faces $S$ (Table 5) for both current and climate scenarios. This result is in line with previous studies, which pointed out that increasing the window size on the southern facade can reduce the heating energy demand (e.g. Gasparella et al. 2011; Jaber and Ajib 2011). In contrast, the cooling demands are minimized when the building faces $\mathrm{N}$ and maximized when facing SW (Table 5). Although the main contribution to the total energy demand for both climates is given by the heating demand (93\% and $82 \%$ for the current and future climate, respectively), the considerable decrease of the heating/cooling demand ratio for the future climate (4.5) compared to the current climate (12.8) affects - albeit in a limited manner - the role of the orientation for the analyzed building. Hence, the decreasing value of this ratio indicates a different role of the building orientation in further possible future climate scenarios (e.g. 2080), for which the abovementioned ratio will most likely further decrease; thus, especially for this type of building where a large part of the total glazing area is present on one single facade, the potential effect on heating 
and cooling demands needs to be carefully assessed. As an example, orienting the facade with most of the glazing towards $\mathrm{N}$ might be a convenient solution from a climate-change perspective. In contrast, in the cases where solar shading is applied (SS and SS + TR), the effect of the orientation on the cooling demand is limited by reducing the solar heat gain through the transparent surfaces (Fig. 10), whereas no negative effects are present in terms of heating demand. As a consequence, for the case under examination, orienting the building towards $\mathrm{N}$ represents the least beneficial option in terms of total energy demand, since heating demand is maximized for that building orientation, while orienting it towards $S$ is the most advantageous one (Fig. 11).

Finally, it must be noted that the total energy demand reduction predicted for the $\mathrm{BC}$ when the optimal orientation is adopted $(\mathrm{S},-4.4 \%$ and $-2.9 \%)$ might be higher or comparable to the savings (averaged over eight orientations) obtained by applying some passive adaptation measures (SWR_RW, SWR_R, GR, NV for both climates, SS for the current climate). On the other hand, the effect of the building orientation on the total energy demand is lower when compared to the most effective passive adaptation measures considered (SS for the future climate, TR and SS + TR for both climates).

\section{Limitations and conclusions}

The performance of a detached, lightweight, semi-portable one-person house located in the southeastern part of the Netherlands is presented in terms of heating, cooling and total energy demands. The impact of several passive climate adaptation measures as well as building orientation is evaluated for two climate scenarios: current and future climate (2050).

Although the study is based on a large number (144) of BES simulations, it is subjected to some limitations that present options for further research:

- The building energy simulations are performed for one specific location and climate zone (temperate oceanic climate, Köppen and Geiger 1954; cool humid, ASHRAE 2013) in the Netherlands. The type of climate across the Netherlands varies from cool humid to mixed humid; in addition, different local wind speed conditions occur (NNI 2013). In conclusion, the effectiveness of different adaptation measures and the effect of the orientation could possibly change for the same climate zone, due to local meteorological conditions, or for different climate zones, thus resulting in different heating/cooling demand ratio.

- Other aspects (not considered in the present paper) need to be taken into account in order to determine the optimal orientation of the building in practice. For instance, the effect of orientation on electricity consumption for lighting and visual comfort.

- The building is considered to be isolated. This choice was made to evaluate the impact of orientation and passive adaptation measures, i.e. without additional factors such as shadowing resulting from surrounding buildings. However, this residential building is designed to be temporarily installed in peripheral and derelict areas, hence the assumption of considering it as an isolated building seems to be reasonable for the present study.

- The HVAC system is considered to be ideal. This assumption is made since it is not an objective of the present paper to investigate the effect of the type of HVAC system on heating and cooling loads. Further work can include an assessment of the impact of different HVAC systems on heating and cooling demand for the building under investigation.

Based on the results of the building energy simulations reported in the present paper, it can be concluded that:

- The ratio of heating/cooling energy demand for the base case is 12.8 and 4.5 for the current and future climate scenarios, respectively. Hence, although this ratio is reduced by almost a factor three, for the Dutch climate the heating energy demand will still be dominant in 2050 .

- The most effective (single) passive adaptation measure to limit the cooling demand is the application of automated movable exterior solar shading, which entails a reduction of $58 \%$ and $48 \%$ for current and future climates, respectively. In terms of heating demand, increasing the thermal resistance of the envelope yields the highest energy savings ( $-8 \%$ for both climate scenarios). Combining the two aforementioned measures leads to a considerable reduction of the total energy demand $(-11 \%$ and $-15 \%$ for current and future climate scenario, respectively).

- Modest variations (within about $1 \%$ ) of the total energy demand are obtained when green roof, high shortwave reflectivity roof or roof and walls are employed, whereas the impact of natural ventilation is slightly higher $(-2 \%$ for both climate scenarios).

- The building orientation affects the energy demands for both heating and cooling and in both climate scenarios. For instance, in the current climate the heating demand varies between $-5.2 \%(\mathrm{~S})$ to $+3.2 \%(\mathrm{~N}, \mathrm{NW})$ and the cooling demand between $-31.0 \%(\mathrm{~N})$ and $+22.5 \%(\mathrm{SW})$, compared to the average over eight orientations. In total, given the higher weight of the heating demand in both climates, the most favorable building orientation is $\mathrm{S}$, with respective reductions of $4.4 \%$ and $2.9 \%$ for the current and the future climate.

- When the optimal orientation (S) is adopted, the reduction of total energy demand (for heating and cooling) for the base case is higher or comparable to the reductions 
obtained by employing some adaptation measures (SWR RW, SWR_R, GR, NV for both climates, SS for the current climate). Conversely, the effect of the orientation on the reduction of the total energy demand is lower when compared to the most effective adaptation measures analyzed in the present study (SS for the future climate, TR and SS + TR for both climates).

- The decreasing ratio of heating/cooling energy demand suggests a different role of the building orientation in future climates. For instance, orienting the building towards $\mathrm{N}$ in a future climate scenario may reduce the total energy demand for heating and cooling by about $2 \%$, whereas an increase of about $1 \%$ is obtained for the same orientation $(\mathrm{N})$ in the current climate.

\section{Acknowledgements}

This research was financially supported by the $\mathrm{PhD}$ Impulse Program of the Eindhoven University of Technology, in collaboration with the construction company Heijmans B.V., the Netherlands. Twan van Hooff is currently a postdoctoral fellow of the Research Foundation Flanders (FWO) and acknowledges its financial support (project FWO 12R9718N).

Open Access: This article is distributed under the terms of the Creative Commons Attribution 4.0 International License (http://creativecommons.org/licenses/by/4.0/), which permits unrestricted use, distribution, and reproduction in any medium, provided you give appropriate credit to the original author(s) and the source, provide a link to the Creative Commons license, and indicate if changes were made.

\section{References}

Abanda FH, Byers L (2016). An investigation of the impact of building orientation on energy consumption in a domestic building using emerging BIM (Building Information Modelling). Energy, 97: 517-527.

Aebischer B, Catenazzi G, Jakob M (2007). Impact of climate change on thermal comfort, heating and cooling energy demand in Europe. In: Proceedings ECEEE 2007 Summer study "Saving Energy - Just Do It!", France.

Akbari H, Bretz S, Kurn DM, Hanford J (1997). Peak power and cooling energy savings of high-albedo roofs. Energy and Buildings, 25: 117-126.

Aksoy UT, Inalli M (2006). Impacts of some building passive design parameters on heating demand for a cold region. Building and Environment, 41: 1742-1754.

Alghoul SK, Rijabo HG, Mashena ME (2017). Energy consumption in buildings: A correlation for the influence of window to wall ratio and window orientation in Tripoli, Libya. Journal of Building Engineering, 11: 82-86.
ASHRAE (2001a). International Weather for Energy Calculations (IWEC Weather Files). Users Manual and CD-ROM. American Society of Heating Refrigerating and Air-Conditioning Engineers. Available at https://energyplus.net/weather-location/europe_wmo_ region_6/NLD//NLD_Beek.063800_IWEC

ASHRAE (2001b). ASHRAE Handbook - Fundamentals. Atlanta, GA, USA: American Society of Heating Refrigerating and AirConditioning Engineers.

ASHRAE (2009). ASHRAE Handbook - HVAC Applications. Atlanta, GA, USA: American Society of Heating Refrigerating and AirConditioning Engineers.

ASHRAE (2013). ASHRAE Standard 169-2013. Climatic Data for Building Design Standards. Atlanta, GA, USA: American Society of Heating Refrigerating and Air-Conditioning Engineers.

Arent DJ, Tol RSJ, Faust E, Hella JP, Kumar S, Strzepek KM, Tóth FL, Yan D (2014). Key economic sectors and services. In: Field CB, Barros VR, Dokken DJ, Mach KJ, Mastrandrea MD, et al. (eds), Climate Change 2014: Impacts, Adaptation, and Vulnerability. Part A: Global and Sectoral Aspects. Contribution of Working Group II to the Intergovernmental Panel on Climate Change Fifth Assessment Report. Cambridge, UK: Cambridge University Press.

Bellia L, Marino C, Minichiello F, Pedace A (2014). An overview on solar shading systems for buildings. Energy Procedia, 62: 309-317.

Berardi U, GhaffarianHoseini A, GhaffarianHoseini A (2014). Stateof-the-art analysis of the environmental benefits of green roofs. Applied Energy, 115: 411-428.

Berardi U, Tronchin L, Manfren M, Nastasi B (2018). On the effects of variation of thermal conductivity in buildings in the Italian construction sector. Energies, 11: 872.

Bouwbesluit (2012). Bouwbesluit online. Available at http:// www.bouwbesluitonline.nl/

Bretz SE, Akbari H (1997). Long-term performance of high-albedo roof coatings. Energy and Buildings, 25: 159-167.

Bretz S, Akbari H, Rosenfeld A, Taha H (1992). Implementation of solar-reflective surfaces: Materials and utility programs. Technical Report, LBL-32467. Lawrence Berkeley Lab.

Carbonari A, Rossi G, Romagnoni P (2002). Optimal orientation and automatic control of external shading devices in office buildings. Environmental Management and Health, 13: 392-404.

CCWorldWeatherGen (2013). Climate Change World Weather File Generator Manual (version 1.8). Sustainable Energy Research Group, University of Southampton.

Chalmers P (2014). Climate change: Implications for buildings. Key findings from the Intergovernmental Panel on Climate Change Fifth Assessment Report. Available at http://www.gbpn.org/ newsroom/report-climate-change-implications-buildings

Chan ALS, Chow TT (2013). Energy and economic performance of green roof system under future climatic conditions in Hong Kong. Energy and Buildings, 64: 182-198.

Chin G, Desjarlais A, Estes M, Hitchcock D, Lewis M, Parker D, Rosenthal J, Ross L, Ryan S, Schmeltz R, Turnbull P, Zalph B (2014). Reducing urban heat islands: Compendium of strategies. Cool roofs. Available at https://www.epa.gov/sites/production/files/ 2014-08/documents/coolroofscompendium_ch4.pdf 
Coutts AM, Daly E, Beringer J, Tapper NJ (2013). Assessing practical measures to reduce urban heat: Green and cool roofs. Building and Environment, 70: 266-276.

de Wilde P, Coley D (2012). The implications of a changing climate for buildings. Building and Environment, 55: 1-7.

EnergyPlus (2010). EnergyPlus Documentation-Engineering Reference: The Reference to EnergyPlus Calculations.

Fleiter T, Elsland R, Rehfeldt M, Steinbach J, Reiter U, Catenazzi G, Jakob M, Rutten C, Harmsen R, Dittmann F, Rivière P, Stabat P (2017). Profile of heating and cooling demand in 2015. Heat Roadmap Europe. Available at http://www.heatroadmap.eu

Gaffin SR, Khanbilvardi R, Rosenzweig C (2009). Development of a green roof environmental monitoring and meteorological network in New York City. Sensors, 9: 2647-2660.

Gasparella A, Pernigotto G, Cappelletti F, Romagnoni P, Baggio P (2011). Analysis and modelling of window and glazing systems energy performance for a well insulated residential building. Energy and Buildings, 43: 1030-1037.

Gromke C, Blocken B, Janssen W, Merema B, van Hooff T, Timmermans H (2015). CFD analysis of transpirational cooling by vegetation: Case study for specific meteorological conditions during a heat wave in Arnhem, Netherlands. Building and Environment, 83: 11-26.

Heijmans B.V. (2016). Heijmans ONE. Prijsoverzicht en Technische Beschriving. Available at https://www.heijmans.nl/media/filer_ public/1d/a5/1da5cb9c-319d-4b92-8629-5fb6ae254ba0/bijlage_ prijs-technisch_heijmans_one.pdf

Heijmans B.V. (2018). Heijmans ONE. Available at https:// www.heijmans.nl/nl/heijmans-one/

Huang KT, Hwang RL (2016). Future trends of residential building cooling energy and passive adaptation measures to counteract climate change: The case of Taiwan. Applied Energy, 184: $1230-1240$

IEA (2013). Energy Efficient Building Envelopes. Paris: International Energy Agency.

Invidiata A, Ghisi E (2016). Impact of climate change on heating and cooling energy demand in houses in Brazil. Energy and Buildings, 130: 20-32.

ISSO (2011). Publicatie 32: Uitgangspunten Temperatuursimulatieberekeningen. Rotterdam, the Netherlands: Stichting ISSO.

Itard L, Meijer F (2008). Towards a sustainable Northern European housing stock. Figures, facts and future. Delft, the Netherlands.

Jaber S, Ajib S (2011). Optimum, technical and energy efficiency design of residential building in Mediterranean region. Energy and Buildings, 43: 1829-1834.

Jentsch MF, Bahaj AS, James PAB (2008). Climate change future proofing of buildings-Generation and assessment of building simulation weather files. Energy and Buildings, 40: 2148-2168.

Jentsch MF, James PAB, Bourikas L, Bahaj AS (2013). Transforming existing weather data for worldwide locations to enable energy and building performance simulation under future climates. Renewable Energy, 55: 514-524.

Kiwa Nederland B.V. (2012). Nationale Beoordelingsrichtlijn BRL 2202. Rijswijk, the Netherlands.

KNMI (2015). KNMI'14 climate scenarios for the Netherlands. A guide for professionals in climate adaptation. De Bilt, the Netherlands.

Kolokotroni M, Ren X, Davies M, Mavrogianni A (2012). London's urban heat island: Impact on current and future energy consumption in office buildings. Energy and Buildings, 47: 302-311.

Kolokotsa D, Santamouris M, Zerefos SC (2013). Green and cool roofs' urban heat island mitigation potential in European climates for office buildings under free floating conditions. Solar Energy, 95: $118-130$.

Köppen W, Geiger R (1954). Klima der Erde. Wall Map 1:16 Mill. Klett-Perthes. Gotha, Germany.

La Roche P, Berardi U (2014). Comfort and energy savings with active green roofs. Energy and Buildings, 82: 492-504.

Ministerie van VROM (2009). Energiegedrag in De Woning. Den Haag, the Netherlands.

Montazeri H, Blocken B (2017). New generalized expressions for forced convective heat transfer coefficients at building facades and roofs. Building and Environment, 119: 153-168.

NNI (2011). NEN-EN 1991-1-4+A1+C2: Eurocode 1: Actions on structures - Part 1-4: General actions - Wind actions. Delft, the Netherlands: Nederlands Normalisatie-Instituut.

Ortiz J, Fonseca A, Salom J, Garrido N, Fonseca P, Russo V (2016). Comfort and economic criteria for selecting passive measures for the energy refurbishment of residential buildings in Catalonia. Energy and Buildings, 110: 195-210.

Pacheco R, Ordóñez J, Martínez G (2012). Energy efficient design of building: A review. Renewable and Sustainable Energy Reviews, 16: 3559-3573.

Pérez G, Coma J, Martorell I, Cabeza LF (2014). Vertical Greenery Systems (VGS) for energy saving in buildings: A review. Renewable and Sustainable Energy Reviews, 39: 139-165.

Pierangioli L, Cellai G, Ferrise R, Trombi G, Bindi M (2017). Effectiveness of passive measures against climate change: Case studies in Central Italy. Building Simulation, 10: 459-479.

Pino A, Bustamante W, Escobar R, Encinas F, Pino FE (2012). Thermal and lighting behavior of office buildings in Santiago of Chile. Energy and Buildings, 47: 441-449.

Porritt SM, Cropper PC, Shao L, Goodier CI (2012). Ranking of interventions to reduce dwelling overheating during heat waves. Energy and Buildings, 55: 16-27.

Reilly A, Kinnane O (2017). The impact of thermal mass on building energy consumption. Applied Energy, 198: 108-121.

Saadatian O, Sopian K, Salleh E, Lim CH, Riffat S, Saadatian E, Toudeshki A, Sulaiman MY (2013). A review of energy aspects of green roofs. Renewable and Sustainable Energy Reviews, 23: 155-168

Sajjadian SM (2017). Performance evaluation of well-insulated versions of contemporary wall systems-A case study of London for a warmer climate. Buildings, 7(1): 6.

Santamouris M (2014). Cooling the cities-A review of reflective and green roof mitigation technologies to fight heat island and improve comfort in urban environments. Solar Energy, 103: 682-703.

Spanos I, Simons M, Holmes KL (2005). Cost savings by application of passive solar heating. Structural Survey, 23: 111-130.

Sproul J, Wan MP, Mandel BH, Rosenfeld AH (2014). Economic comparison of white, green, and black flat roofs in the United States. Energy and Buildings, 71: 20-27. 
Stevanović S (2015). Parametric study of a cost-optimal, energy efficient office building in Serbia. Energy, 117: 492-505.

Susca T, Gaffin SR, Dell'Osso GR (2011). Positive effects of vegetation: Urban heat island and green roofs. Environmental Pollution, 159: 2119-2126.

Susorova I, Tabibzadeh M, Rahman A, Clack HL, Elnimeiri M (2013). The effect of geometry factors on fenestration energy performance and energy savings in office buildings. Energy and Buildings, 57: 6-13.

Synnefa A, Santamouris M, Akbari H (2007). Estimating the effect of using cool coatings on energy loads and thermal comfort in residential buildings in various climatic conditions. Energy and Buildings, 39: 1167-1174.

Synnefa A, Saliari M, Santamouris M (2012). Experimental and numerical assessment of the impact of increased roof reflectance on a school building in Athens. Energy and Buildings, 55: 7-15.

van Hooff T, Blocken B, Hensen JLM, Timmermans HJP (2014). On the predicted effectiveness of climate adaptation measures for residential buildings. Building and Environment, 82: 300-316.

van Hooff T, Blocken B, Timmermans HJP, Hensen JLM (2016). Analysis of the predicted effect of passive climate adaptation measures on energy demand for cooling and heating in a residential building. Energy, 94: 811-820.

van Kempen P (2000). Marktanalyse en-prognose van airconditioningsystemen. Amsterdam, the Netherlands.

VHK (2008). Elektrische apparatuur in Nederlandse huishoudens. Delft, the Netherlands: van Holsteijn en Kemna B.V.
Waddicor DA, Fuentes E, Sisó L, Salom J, Favre B, Jiménez C, Azar M (2016). Climate change and building ageing impact on building energy performance and mitigation measures application: A case study in Turin, northern Italy. Building and Environment, 102: 13-25.

Walton GN (1983). Thermal Analysis Research Program Reference Manual. NBSSIR 83-2655. Washington, DC, USA.

Wan KKW, Li DHW, Pan W, Lam JC (2012). Impact of climate change on building energy use in different climate zones and mitigation and adaptation implications. Applied Energy, 97: 274-282.

Wang H, Chen Q (2014). Impact of climate change heating and cooling energy use in buildings in the United States. Energy and Buildings, 82: 428-436.

Wong K, Fan Q (2013). Building information modelling (BIM) for sustainable building design. Facilities, 31: 138-157.

Xu X, Yuan D, Sha H, Ji Y, Xu P (2012). Energy consumption simulation of the prototypical building for optimizing the orientation of building model in the simulated environment. In: Proceedings of the International Building Performance Simulation Association (ASim2012), Shanghai, China.

Yildiz Y, Korkmaz K, Özbalta TG, Arsan ZD (2012). An approach for developing sensitive design parameter guidelines to reduce the energy requirements of low-rise apartment buildings. Applied Energy, 93: 337-347.

Zhang Y, Barrett P (2012). Factors influencing occupants' blindcontrol behaviour in a naturally ventilated office building. Building and Environment, 54: 137-147. 